\title{
Performance Evaluation of Drip Irrigation Systems
}

\author{
C.K. Arya ${ }^{1}$, R.C. Purohit ${ }^{2}$, L.K. Dashora ${ }^{1}$, P.K. Singh ${ }^{2}$ and Mahesh Kothari ${ }^{2}$ \\ ${ }^{1}$ College of Horticulture \& Forestry (AU, Kota), Jhalawar (Rajasthan), India \\ ${ }^{2}$ Dept. of Soil \& Water Engineering, CTAE, (MPUAT), Udaipur (Rajasthan), India \\ *Corresponding author
}

\begin{tabular}{|c|c|}
\hline & A B S T R A C T \\
\hline Keywords & \multirow{4}{*}{$\begin{array}{l}\text { The field experiments were conducted to evaluate the performance of drip irrigation } \\
\text { systems at protected cultivation unit of College of Horticulture and Forestry, Jhalawar, } \\
\text { Rajasthan during } 2013-14 \text { and } 2014-15 \text {. The performance of drip system was evaluated on } \\
\text { the basis of parameters like average discharge }\left(Q_{a v g}\right) \text {, field emission uniformity }\left(E_{\mathrm{f}}\right) \text {, } \\
\text { design emission uniformity }\left(\mathrm{EU}_{\mathrm{d}}\right) \text {, application efficiency }\left(\mathrm{EU}_{\mathrm{a}} \text { and } \mathrm{E}_{\mathrm{a}}\right) \text {, coefficient of } \\
\text { variance }\left(\mathrm{C}_{\mathrm{v}}\right) \text { and statistical uniformity coefficient }(\mathrm{SUC}) \text {. The distribution efficiency } \\
\text { values of } 93.63,93.46 \text { per cent for NVPH and } 95.70,95.38 \text { per cent for ECPH environment } \\
\text { and SUC values of } 92.38,91.97 \text { per cent for NVPH and } 94.46,94.28 \text { per cent for ECPH } \\
\text { during both the year respectively were estimated. As per the ASAE Standards, the } \mathrm{C}_{\mathrm{v}} \text { is } \\
\text { classified as good performance for entire experiment during both the years since calculated } \\
\mathrm{C}_{\mathrm{v}} \text { is less than } 0.10 \text {. The designed drip irrigation system was operated excellently as the } \\
\text { values of EU were nearly equal or more than to design criteria of } 90 \text { per cent in each case. }\end{array}$} \\
\hline $\begin{array}{l}\text { Drip system, } \\
\text { Uniformity } \\
\text { Coefficient, } \\
\text { Application } \\
\text { efficiency, } \\
\text { Coefficient of } \\
\text { variance. }\end{array}$ & \\
\hline Article Info & \\
\hline $\begin{array}{l}\text { Accepted: } \\
20 \text { March } 2017 \\
\text { Available Online: } \\
10 \text { April } 2017\end{array}$ & \\
\hline
\end{tabular}

\section{Introduction}

Efficient use of available irrigation water is essential for increasing agricultural productivity for the alarming Indian population. As the population of India is increasing day by day, the pressure on agriculture is increasing in the same way. Rajasthan is the largest state of the country in term of geographical area. It is well endowed with the land and sunshine but is less fortune in available water resources. Ground water is main source of irrigation which is most precious and contributes only 2.9 per cent of total ground resource of the country (Yadav and Singh, 2008). Root system of most the vegetables are confined only in upper layer of soil and required frequent irrigation. Thus, micro- irrigation/drip irrigation is an effective, efficient and economic viable method for irrigation in vegetables. Drip irrigation has the greatest potential for the efficient use of water and fertilizers. For minimizing the cost of irrigation and fertilizers, adoption of drip irrigation with fertigation is essential which maximize the nutrient uptake while using minimum amount of water and fertilizer (Roma and Arun, 2014). The drip irrigation adoption increases water use efficiency (60-200\%), saves water (20-60\%), reduces fertilization requirement (20-33\%) through fertigation, produces better quality crop and increases yield (7-25\%) as compared with conventional irrigation Kaushal et al., (2012). 
The method consists of water source, pumping unit, mixing chamber, mainline, sub-main, laterals and emitters. The main line delivers water to the sub-mains and they carry water into the laterals. Irrigation is accomplished by emitters or drippers made up of small diameter polyethylene tubes installed in the lateral lines at selected spacing near the plants. The emitters deliver water at a desired rate near the plants. Though, the system slowly and partially wets the soil near the plant root zone, but, it is practically difficult to apply the equal amount of water to all plants within a field unit. Therefore, in most cases, even a well designed system gives poor uniformity as a consequence the yields are pretentious (Bhatnagar and Srivastava, 2003). A best and desirable feature of trickle irrigation is that the uniform distribution of water is possible, which is one of the most important parameters in design, management, and adoption of this system. Ideally, a well designed system applies nearly equal amount of water to each plant, meets its water requirements, and is economically feasible. But, due to manufacturing variations, pressure differences, emitter plugging, aging, frictional head losses, irrigation water temperature changes and emitter sensitivity results in flow rate variations even between two identical emitters (Mizyed and Kruse, 2008).

The uniform distribution is reflected by the values of uniformity coefficient $(C U)$ which in turn suggests the variability in the amount of water received by a plant in a subunit system. A system with uniformity co-efficient of at least $85 \%$ is considered appropriate for standard design requirements. However, the distribution uniformity $(D U)$ and the uniformity coefficient (CU) are function of hydraulic head and slope of lateral and submain lines. The coefficient of uniformity generally follows a linear relationship either with head or slope. The $C U$ and $D U$ decrease substantially at sub-main slopes steeper than $30 \%$ (Ella et al., 2009). The experiment was undertaken with objective to evaluate the performance of drip irrigation systems laid down in the study area.

\section{Materials and Methods}

\section{Study area}

The field experiments were carried out at protected cultivation unit of College of Horticulture and Forestry, Jhalawar, Rajasthan during 2013-14 and 2014-15. This district is located at $23^{\circ} 45^{\prime}$ to $24^{\circ} 52^{\prime} \mathrm{N}$ Latitude and $75^{\circ} 27^{\prime}$ to $76^{\circ} 56^{\prime}$ E-Longitude in south eastern Rajasthan. Agro-climatically, the district falls in Zone V, known as Humid South Eastern Plain. The rainfall is mostly concentrated in four monsoon months of June to September besides, some regeneration in the winter months. On the basis of available rainfall data, the average annual rainfall in the study area is $910 \mathrm{~mm}$ (Singh, 2016). The district is having conspicuous physiographic variations comprising undulating or flat terrain.

\section{Performance of drip irrigation system}

Performance evaluation of drip irrigation system installed at naturally ventilated poly house (NVPH) and environmentally controlled poly house (ECPH) was made for the efficient working of the system. Four laterals were selected from inlet end, $1 / 3^{\text {rd }}$ down, $2 / 3^{\text {rd }}$ down and far end on the submain.

Similarly, the discharge of emitters was measured in catch can for 3 minutes from the emitters at the inlet end, $1 / 3^{\text {rd }}$ down, $2 / 3^{\text {rd }}$ down and far end on each selected lateral. The constant operating pressure of $1.0 \mathrm{~kg} / \mathrm{cm}^{2}$ was maintained throughout the period of application. Evaluation of the system was done by the equations as suggested by different scientists. 


\section{Distribution efficiency}

The distribution efficiency determines how uniformly irrigation water can be distributed through a drip irrigation system in to the field. $\mathrm{Wu}$ and Gitlin (1973) used the statistical approach for obtaining irrigation uniformity as suggested by Christiansen. They gave the following relationship:

$E d=\left(1-\frac{\Delta q a}{q m}\right) 100$

Where, $\mathrm{E}_{\mathrm{d}}=$ distribution efficiency $(\%)$ or uniformity coefficient, $\mathrm{q}_{\mathrm{m}}=$ mean emitter flow rate $(1 / h)$

$\Delta q_{\mathrm{a}}=$ average absolute deviation of each emitter flow from the mean emitter flow

\section{Application efficiency}

The application efficiency is defined as the ratio of water required in the root zone to the total amount of water applied and can be expressed as,

$$
E a=\left(\frac{Q \min }{Q \text { avg }}\right) 100
$$

Where, $\mathrm{E}_{\mathrm{a}}=$ application efficiency, \%, $\mathrm{Q}_{\min }=$ minimum emitter flow rate $(1 / \mathrm{h})$, $\mathrm{Q}_{\text {avg }}=$ average emitter flow rate $(1 / \mathrm{h})$

\section{Field emission uniformity $\left(\mathbf{E U}_{\mathrm{f}}\right)$}

To define the uniformity of water application by drip irrigation method, Keller and Karmeli (1974) suggested two parameters, namely field emission uniformity $\left(\mathrm{EU}_{\mathrm{f}}\right)$ and absolute emission uniformity $\left(\mathrm{EU}_{\mathrm{a}}\right)$. The relations are given as under:

$$
E U_{f}=\left(\frac{q_{n}}{q_{a}}\right) \times 100
$$

Where, $\mathrm{EU}_{\mathrm{f}}=$ Field emission uniformity, $\mathrm{q}_{\mathrm{n}}=$ The average of lowest $1 / 4^{\text {th }}$ of the emitter flow rate $(1 / \mathrm{h}), \mathrm{q}_{\mathrm{a}}=$ The average of all emitters flow rate $(1 / \mathrm{h})$

\section{Absolute emission uniformity $\left(\mathbf{E U}_{\mathbf{a}}\right)$}

$100 \times\left[\frac{Q \text { min }}{Q a v g}+\frac{\mathrm{EU}_{\mathrm{a}}}{Q x}\right] \times \frac{1}{2}$

Where, $\mathrm{EU}_{\mathrm{a}}=$ Absolute emission uniformity, $\mathrm{Q}_{\min }=$ minimum flow rate through emitter, $1 / \mathrm{hQ}_{\text {avg }}=$ average flow rate through emitter $(1 / h), Q_{x}=$ average of the highest $1 / 8^{\text {th }}$ of the emitters flow rate $(1 / h)$.

\section{Design emission uniformity $\left(\mathbf{E U}_{\mathrm{d}}\right)$}

Keller and Karmeli (1974) suggested design emission uniformity by the following equation:

$E U_{d}=100\left(1-1.27 \frac{V_{m}}{N_{e}^{0.5}}\right) \frac{q_{\min }}{q_{\text {avg }}} \ldots \ldots . .(5)$

Where, $\mathrm{EU}_{\mathrm{d}}=$ design emission uniformity, $(\%)$, $\mathrm{V}_{\mathrm{m}}=$ manufacturing coefficient of variation $\mathrm{N}_{\mathrm{e}}=$ number of emitters per plant, $\mathrm{q}_{\min }=$ minimum flow rate through emitter, $\mathrm{l} / \mathrm{h}$ $\mathrm{q}_{\text {avg }}=$ average flow rate through emitter, $1 / \mathrm{h}$

\section{Coefficient of variation $\left(\mathrm{C}_{\mathrm{v}}\right)$}

$C_{v}=\frac{S}{\bar{q}}$

Where, $C_{v}=$ Coefficient of variation of emitter flow, $\mathrm{S}=$ Standard deviation of the emitter flow

Statistical uniformity coefficient

$\mathrm{SUC}=1-\mathrm{Cv}$ 
Where, SUC =Statistical Uniformity Coefficient,

\section{Results and Discussion}

The various parameters to evaluate the performance of drip irrigation system viz., average discharge $\left(\mathrm{Q}_{\text {avg }}\right)$, field emission uniformity $\left(\mathrm{EU}_{\mathrm{f}}\right)$, design emission uniformity $\left(E_{d}\right)$, application efficiency $\left(E_{a}\right.$ and $\left.E_{a}\right)$, coefficient of variance $\left(\mathrm{C}_{\mathrm{v}}\right)$ and statistical uniformity coefficient (SUC) were calculated for both the environments separately and depicted in table 1.

It is observed from the table 1 that the average discharge rate of emitters was $1.79,1.71 \mathrm{lph}$ for $\mathrm{NVPH}$ and $1.85,1.81 \mathrm{lph}$ for $\mathrm{ECPH}$ during the year 2013-14, 2014-15 respectively.

The distribution efficiency values were 93.63 , 93.46 per cent for NVPH and 95.70, 95.38per cent for ECPH during the year 2013-14, 2014-15 respectively. The field emission uniformity values were $89.99,89.00$ per cent for NVPH and 92.92, 92.20 per cent for ECPH during the year 2013-14, 2014-15 respectively. The absolute emission uniformity values were $88.58,88.17$ per cent for NVPH and 90.43, 90.82 per cent for ECPH during year 2013-14, 2014-15 respectively. The design emission uniformity values for the drip irrigation system were 76.86, 76.64 per cent for NVPH and 80.59, 81.4 per cent for ECPH during year 2013-14, 2014-15 respectively. Similarly, the application efficiencies were $85.09,85.35$ per cent for NVPH and $86.69,87.78$ per cent for ECPH during year2013-14, 2014-15 respectively.

The low $\mathrm{C}_{v}$ indicate a good performance of the system throughout the cropping season. The calculated values of $C_{v}$ were $0.076,0.08$ for NVPH and $0.05,0.05$ for ECPH during both the years. Statistical Uniformity Coefficient (SUC) is highly correlated to system uniformity. It is used to show the system uniformity. The high value of SUC indicates a good performance of the system. The calculated values of SUC were 92.38, 91.97 per cent for NVPH and 94.46, 94.28 per cent for ECPH during year 2013-14, 2014-15 respectively.

The average discharge of emitters dropped from 1.79 to $1.71 \mathrm{lph}$ and from 1.85 to 1.81 lph during second year for NVPH and ECPH, respectively. This may be due to the partial clogging caused by algae infestation. In addition, the used laterals, probably the internal spiral layer of the laterals, stretched during the lateral installation or the retrieving operation at the end of last season, which led to decreased discharge (Mostafa et al., 2013). Changade et al., (2009) reported emission uniformity of system as 90.58 per cent and Edossa and Emana (2011) found average emission uniformity of the system as 89 per cent.The same findings were quoted by Sah $e t$ al., (2010) and Harmanto et al., (2005) which confirms the result of this study. The EU values during second year were found as decreased from first year. In addition, by the partial clogging of some emitters, these results probably influenced some defects occurring during the retrieving operation at the end of the last year. Mirjat et al., (2010) reported the $\mathrm{E}_{\mathrm{a}}$ values for laterals with smooth emitters and spiral emitters averaging 82.7 per cent and 89.4 per cent respectively which is in agreement with the present study.

As the values of $\mathrm{C}_{\mathrm{v}}$ were higher during first year as compare to second year. The problem must have been due to the clogging of some emitters. 
Table.1 Performance parameters to evaluate drip irrigation system in the study area

\begin{tabular}{|c|c|c|c|c|c|c|c|c|c|}
\hline Year & Environment & $\begin{array}{l}\mathbf{Q}_{\text {avg }} \\
\text { lph }\end{array}$ & $\begin{array}{c}\text { Ed } \\
\%\end{array}$ & $\begin{array}{c}\mathbf{E U}_{\mathbf{f}} \\
\%\end{array}$ & $\begin{array}{c}\mathbf{E U}_{\mathbf{a}} \\
\%\end{array}$ & $\begin{array}{c}\mathbf{E} \mathbf{U}_{\mathbf{d}} \\
\%\end{array}$ & $\begin{array}{c}\text { Ea } \\
\%\end{array}$ & $\mathbf{C}_{\mathrm{v}}$ & $\begin{array}{c}\text { SUC } \\
\%\end{array}$ \\
\hline \multirow{2}{*}{ 2013-14 } & NVPH & 1.79 & 93.63 & 89.99 & 88.58 & 76.86 & 85.09 & 0.0762 & 92.38 \\
\hline & ЕСРН & 1.85 & 95.70 & 92.92 & 90.43 & 80.59 & 86.69 & 0.0553 & 94.46 \\
\hline \multirow{2}{*}{ 2014-15 } & NVPH & 1.71 & 93.46 & 89.00 & 88.17 & 76.64 & 85.35 & 0.0803 & 91.97 \\
\hline & ЕСРН & 1.81 & 95.38 & 92.20 & 90.82 & 81.41 & 87.78 & 0.0572 & 94.28 \\
\hline
\end{tabular}

In addition, the used laterals may get stretched during the lateral installation or the retrieving operation at the end of first year. As per the ASAE Standards, the $\mathrm{C}_{\mathrm{v}}$ is classified as good performance for entire experiment during both the years since calculated $\mathrm{C}_{\mathrm{v}}$ is less than 0.10. Similar results are estimated by Patel and Rajput (2007) for in-line dripper, they reported to between 0.04 and 0.06 , indicating a good performance of the drip system which is in agreement with the results of present study.

Sah et al., (2010) evaluated hydraulic performance of drip irrigation system and reported the value of SUC as the range of 86.15 per cent to 90.82 per cent respectively meeting ASAE standards. Thus the results obtained are in agreement with work done on SUC by other scientists.

In conclusion, as per the results of different parameters like field emission uniformity $\left(\mathrm{EU}_{\mathrm{f}}\right)$, design emission uniformity $\left(\mathrm{EU}_{\mathrm{d}}\right)$, application efficiency $\left(\mathrm{EU}_{\mathrm{a}}\right.$ and $\left.\mathrm{E}_{\mathrm{a}}\right)$, coefficient of variance $\left(\mathrm{C}_{\mathrm{v}}\right)$ and statistical uniformity coefficient (SUC) of drip irrigation system installed in both the environments, the good performance of drip irrigation system was found meeting ASAE standards. As per the recommendation of Keller and Karmeli (1974), it can be apprehended from the data that the designed drip irrigation system was operated excellently as the values of EU were nearly equal or more than to design criteria of 90 per cent in each case.

\section{References}

Bhatnagar, P.R. and R.C. Srivastava. 2003. Gravity-fed drip irrigationsystem for hilly terraces of the northwest Himalayas. Irr. Sci., 21: 151-157.

Changade, N.M., Chavan, M.C., Jadhav, S.B. and Bhagyawant, R.G. 2009. Determination of emission uniformity of emitter in gravity fed drip irrigation System. Int. J. Agri. Engi., 2(1): 88-91.

Edossa, D.C. and Emana, T.G. 2011. Interaction effects of drip irrigation level and planting method on water use efficiency, irrigation uniformity and yield in green pepper (Capsicum annuum L.). Philippine Agri. Scientist, 94(4): 350-358.

Ella, V.B., M.R. Reyesand, R., Yoder. 2009. Effect of hydraulic head and slope on water distribution uniformity of a lowcost drip irrigation system. App. Eng. in Agric., 25(3): 349-356.

Harmanto, Salokhea, V.M., Babelb, M.S. and Tantauc, H.J. 2005. Water requirement of drip irrigated tomatoes grown in greenhouse in tropical environment. Agri. Water Manage., 71: 225-242.

Kaushal, A., Patole, R. and Singh, K.G. 2012. 
Drip irrigation in sugarcane: A review, J. Agri. Rev., 33: 211-219.

Keller, J. and Karmeli, D. 1974. Trickle irrigation design parameters. Transactions of the American Society of Agri. Engi., 17(4): 678-684.

Mirjat, M.S., Mirjat, M.U. and Chandio, F.A. 2010. Water distribution pattern, discharge uniformity and application efficiency of locally made emitters used in a trickle subunit. Pak. J. Agri., Agril. Engg., Vet. Sci., 26(1): 1-15.

Mizyed, N. and E.G. Kruse. 2008. Emitter discharge variability ofsubsurface drip irrigation in uniform soils: Effect on water application uniformity. Trans. of the ASAE, 26: 451-458.

Mostafa, H. and Thörmann, H.H. 2013.Onfarm evaluation of low-pressure drip irrigation system for smallholders. Soil \& Water Res., 8: 87-95.

Patel, N. and Rajput, T.B.S. 2007. Effect of drip tape placement depth and irrigation level on yield of potato. Agri. Water
Manage., 8: 209-223.

Roma Kumari and Arun Kaushal. 2014. Drip Fertigation in Sweet Pepper: A Review, Int. J. Engi. Res. Appli., 4(8): 144-149.

Sah, D.N., Purohit, R.C., Virendra Kumar, Shukla, A.K. and Jain, S.K. 2010. Design, construction and evaluation of low pressure and low cost drip irrigation system. Int. Agri. Engi. J., ,19(2): $32-38$.

Singh, B. 2016. Variability and trend analysis of rainfall data of Jhalawar district of Rajasthan, India. J. Appl. Natural Sci., 8(1): 116-121.

$\mathrm{Wu}$, I.P. and Gitlin, H.M. 1973. Hydraulics and uniformity of drip irrigation. $J$. Irrigation and Drainage Division, ASCE, 99(2): 157-167.

Yadav, K.K. and Singh, P.K. 2008. Ground water recharge through percolation ponds in Rajasthan. Indian Farming, $14-15$.

\section{How to cite this article:}

Arya, C.K., R.C. Purohit, L.K. Dashora, P.K. Singh and Mahesh Kothari. 2017. Performance Evaluation of Drip Irrigation Systems. Int.J.Curr.Microbiol.App.Sci. 6(4): 2287-2292. doi: https://doi.org/10.20546/ijcmas.2017.604.266 